\title{
A note of appreciation for Prof. Cristobal dos Remedios on behalf of Biophysical Reviews
}

\author{
Damien Hall ${ }^{1}$ (iD
}

Received: 30 January 2019 / Accepted: 11 February 2019 / Published online: 19 February 2019

(C) International Union for Pure and Applied Biophysics (IUPAB) and Springer-Verlag GmbH Germany, part of Springer Nature 2019

\begin{abstract}
Following the initial five-year tenure (2009-2014) of the founding Chief Editor, Dr. Jean Garnier, Prof. Cristobal dos Remedios (University of Sydney) assumed responsibility for Biophysical Reviews as the second Chief Editor (2014-2019). Under his stewardship, Biophysical Reviews has become a six issue per year journal, publishing approximately 100 reviews per year. At the conclusion of his five-year tenure as Chief Editor (and at the age of 78), Cris is stepping down, leaving the journal well placed to apply for (and receive) an impact factor in 2020. On behalf of the journal, I would like to take the occasion of his retirement as Chief Editor to thank Cris for his dedicated service to Biophysical Reviews, and also welcome him to his new position as Emeritus Chief Editor.
\end{abstract}

I first met Cris at a conference in Japan in 2008. At that time, Prof. Cristobal dos Remedios of the University of Sydney, was one of the powers within both, the Executive of the International Union of Pure and Applied Biophysics (IUPAB), and the Editorial Board of Biophysical Reviews, the IUPAB's newly developed journal. When Cris took over as Chief Editor in 2014, he set to task in expanding and invigorating the journal in order to make the necessary changes required for a successful bid for an impact factor application, five to six years henceforth. Under Cris's stewardship, Biophysical Reviews has risen from its initial format as a low-volume quarterly journal (around four articles per issue), to a six issue per year publication, with each printing regularly containing $15-20$ articles per issue. In pursuing this endeavour, Cris has lead from the front, displaying confidence in the firmity of Biophysical Reviews, by publishing a number of articles within it (Wolfe et al. 2011; Estigoy et al. 2009; Wriggers et al. 2012; Lal et al. 2015; McNamara et al. 2015; Pluess et al. 2015; Kanellis and dos Remedios 2018; dos Remedios 2018a, b). He has also facilitated a series of special issue topics (Morales and dos Remedios 2011; dos Remedios and Nakamura 2012; Hall and dos Remedios 2013; Li and dos Remedios 2015; Hall and dos Remedios 2017; Li and dos Remedios 2017) and written a bevy

Damien Hall

damien.hall@protein.osaka-u.ac.jp; damienhall30@gmail.com

1 Laboratory for Multiscale Structural Biology, Institute for Protein Research, Osaka University, 3-1-Yamadaoka,

Suita, Osaka 565-0871, Japan of interesting general editorials (e.g. dos Remedios 2016; dos Remedios 2018a, b). Over this time, we have seen Biophysical Reviews climb the SCIMAGO rankings within the biophysics category, such that it currently ranks 40th out of a total of 160 journals listed within the division (lying within the bracket of such journals such as Biophysical Chemistry, Physical Biology, Biopolymers and BBA). This situation is all the more remarkable for the fact that Biophysical Reviews is still yet to obtain an impact factor! While increasing the amount of published content, Cris has been cognizant of the IUPAB mission of promoting Biophysical Reviews as a platform accessible to scientists from as diverse and international a background as possible. In pursuit of this task, Cris (together with other Editorial staff), has played a very proactive role, by encouraging the publication of the contents of IUPAB workshops as special issues and, perhaps most practically, by improving the readability of submitted manuscripts through gratis editing and polishing. Along the way, Cris has been an excellent scientific role model, demonstrating a refreshingly frank honesty, along with the necessary balance of rigour and pragmatism required to meet publishing deadlines and consistently produce a high-quality academic product.

My professional association with Biophysical Reviews started in 2010 when, on the strength of a well-received review (Hall and Hoshino 2010), I was invited to join the Editorial Board by the founding Chief Editor, Dr. Jean Garnier. In 2015, I was made Deputy Editor of the journal, and at the time of writing, I have just been appointed by the IUPAB Executive, as the new Chief Editor of Biophysical 
Reviews. Acting in this capacity, I would like to finish this Editorial commentary by congratulating Cris dos Remedios on a truly excellent performance during his tenure leading the journal and state that it has been a genuine pleasure to serve alongside him, in the supporting role of Deputy Editor. With the coming application and obtainment of an impact factor for the journal in 2020, the future looks extremely positive for the IUPAB Biophysical Reviews as the principal platform for disseminating topical reviews on the subject-a situation whose origins will be rooted in the hard work put in by Cristobal dos Remedios over the last five years.

Publisher's note Springer Nature remains neutral with regard to jurisdictional claims in published maps and institutional affiliations.

\section{References}

dos Remedios CG (2016) The evolution of Biophysical Reviews. Biophys Rev 8(1):1-3

dos Remedios CG (2018a) Reviews arising from the 2017 conference of the Australian Society for Biophysics and the Japanese Society for Biophysics. Biophys Rev 10(5):1215-1220

dos Remedios CG (2018b) An historical perspective of the discovery of titin filaments -part 2. Biophys Rev 10(4):1201-1203

dos Remedios CG, Nakamura H (2012) Editorial. Spec Issue: Comput Biophys Biophys Rev 4(3):149-151

Estigoy CB, Pontén F, Odeberg J, Herbert B, Guilhaus M, Charleston M, Ho JWK, Cameron D, Dos Remedios CG (2009) Intercalated discs: multiple proteins perform multiple functions in non-failing and failing human hearts. Biophys Rev 1(1):43

Hall D, dos Remedios CG (2013) Foreword to the biophysics of proteinprotein and protein-ligand interactions in dilute and crowded media- a special issue in honor of Allen Minton's 70th birthday. Biophys Rev 5(2):57-60

Hall D, dos Remedios CG (2017) Special issue of Biophysical Reviews dedicated to the 19(th) IUPAB Conference in Edinburgh, Scotland (July 2017). Biophys Rev 9(4):269-271

Hall D, Hoshino M (2010) Effects of macromolecular crowding on intracellular diffusion from a single particle perspective. Biophys Rev 2(1):39-53

Kanellis VG, dos Remedios CG (2018) A review of heavy metal cation binding to deoxyribonucleic acids for the creation of chemical sensors. Biophys Rev 10(5):1401-1414

Lal S, Li A, Allen D, Allen PD, Bannon P, Cartmill T, Cooke R, Farnsworth A, Keogh A, dos Remedios CG (2015) Best practice biobanking of human heart tissue. Biophys Rev 7(4):399-406

Li A, dos Remedios CG (2015) Special issue on human heart failure. Biophys Rev 7(1):1-3

Li A, dos Remedios CG (2017) Special issue on titin and its binding proteins in striated muscle. Biophys Rev 9(3):177-178

McNamara JW, Li A, dos Remedios CG, Cooke R (2015) The role of super-relaxed myosin in skeletal and cardiac muscle. Biophys Rev 7(1):5-14

Morales MM, dos Remedios CG (2011) Biophysical educational experiment: science and goodwill in Latin America and Africa. Biophys Rev 3(3):101

Pluess M, Daeubler G, dos Remedios CG, Ehler E (2015) Adaptations of cytoarchitecture in human dilated cardiomyopathy. Biophys Rev $7(1): 25-32$

Wolfe JE, Ishiwata S, Braet F, Whan R, Su Y, Lal S, Dos Remedios CG (2011) Spontaneous oscillatory contraction (SPOC): autooscillations observed in striated muscle at partial activation. Biophys Rev 3(2):53-62

Wriggers W, Olson WK, dos Remedios CG (2012) Computational opportunities for remote collaboration and capacity building afforded by Web 2.0 and cloud computing. Biophys Rev 4(3):153-160 